\title{
Missed Diagnosis of Cancer in Critically Ill Patients: A Single-Center Experience
}

\author{
Berlot $\mathbf{G}^{1^{\star}}$, Calderan $\mathbf{C}^{1}$, Moro $\mathbf{V}^{1}$, Bussani $\mathbf{R}^{2}$ and Zandonà $\mathrm{L}^{2}$ \\ ${ }^{1}$ Department of Anaesthesia and Intensive Care Medicine, University of Trieste, Trieste, Italy \\ ${ }^{2}$ Department of Pathology, University of Trieste, Trieste, Italy
}

*Corresponding author: Giorgio Berlot, Department of Anaesthesia and Intensive Care, Cattinara Hospital, Strada di Fiume 447, Trieste, 34149, Italy, Tel: + +39040-3994540; ++39040-912278; E-mail: berlot@inwind.it

Received date: Nov 15, 2016; Accepted date: Nov 19, 2016; Published date: Nov 22, 2016

Copyright: (c) 2016 Berlot G, et al. This is an open-access article distributed under the terms of the Creative Commons Attribution License, which permits unrestricted use, distribution, and reproduction in any medium, provided the original author and source are credited.

\begin{abstract}
Purpose and methods: In order to evaluate the rate of missed diagnoses (MD) of tumors in critically ill patients died in our Intensive Care Unit (ICU) and correlate them with the outcome, all the autopsy records from January 1 st, 1996 and December $31^{\text {st }}, 2014$ have been reviewed. When the tumor was not diagnosed during the admission but discovered only at the post-mortem examination, the effect of the MD on the outcome was classified according to the Goldman's criteria.

Results: A total of, 1045 autopsies were examined; a solid or hematological cancer was discovered in 74 cases (7\%, 50 M, 24 F, age 75.5, IQR 29-90 years). Major discrepancies occurred in 42 patients, but only in one of them $(2.4 \%)$ a class 1 error was identified; in the other cases the MD did not influence the outcome (class 2 errors) due to the underlying conditions determining the ICU admission and/or the very short length of stay in the ICU; for another 32 patients the MD were considered without clinical relevance.
\end{abstract}

Conclusions: In our experience, autopsy remains an extremely valuable tool to detect MD and to improve the clinical and diagnostic procedures.

Keywords: Autopsy; Missed diagnosis; Intensive care unit; Tumors

\section{Introduction}

Several studies demonstrated that the rate of diagnostic discrepancies discovered at the autopsy is still high in patients dying both in the regular wards and in the Intensive Care Unit (ICU), ranging from 5 to $40 \%$ and from 7 to $32 \%$, respectively [1]. Despite a worldwide decrease in their numbers, which started several decades ago, autopsies represent a valuable tool to improve the clinical practice primarily by enlightening possible breakdowns of the diagnostic procedures and/or a wrong interpretation of the available informations $[2,3]$. This particularly applies to ICU patients who are at risk of missed diagnosis (MD) primarily because of the relative lack of specificity of symptoms such as fever, tachycardia, arterial hypotension and disturbances of the consciousness; moreover, the often rapidly evolving clinical course can prevent clinicians from a diagnostic workup not immediately targeted on the life-threatening conditions requiring the admission. A number of investigations demonstrated that infections and cardio-respiratory diseases, including pulmonary embolisms and myocardial infarctions account for a substantial rate of $\mathrm{MD}$ in this population, with variable effects on the outcome ranging from negligible to substantially deadly [1,4-7]. Although the occurrence of autopsy-discovered malignancies is less common [8], yet they can represent as many as $10 \%$ of cases $[9,10]$ in patients admitted for reasons other than tumors. However, independently from their rate of occurrence, the ante-mortem diagnosis of neoplastic diseases in critically ill patients appears relevant for two opposite reasons. On one hand, it could identify acutely ill patients admitted to the ICU who might take some advantage from anti-tumor treatments once the acute phase is over [11]; actually, Taccone et al. [12] demonstrated that the outcome of critically ill patients with already diagnosed solid cancer is similar to that of subjects without cancer.

On the other hand, it could prevent the implementation of costly life-extending procedures which often are associated with heavy side effects but which are devoid of any significant effect on the survival of patients with more advanced and/or metastatic forms, thus leaving space to palliative therapies.

We reviewed both the autopsy and the clinical records of all patients died in our ICU with the double aim (a) to identify the patients died in our ICU in whom a neoplastic disease was discovered only at the postmortem examination; and (b) to correlate this MD with the outcome.

\section{Patients and Methods}

We retrospectively reviewed the autopsy records of the patients dead in our 13-bed general ICU between January $1^{\text {st }}, 1996$ and December $31^{\text {st }}, 2014$. The consent of the local ethical committee was deemed unnecessary because the study was retrospective, did not imply any intervention and the privacy was secured. Our medical-surgical ICU is located inside a 750-bed university hospital, admits about 1000 patients/year coming both from the emergency department and from the regular wards, and has a $23 \%$ mortality rate.

For our study we did not adopted any selection criteria. We did not include in the study (a) patients dying in the coronary care unit or 
Page 2 of 8

cardiac surgery ICU because they are treated in other wards; (b) obstetric and pediatric patients, as they are treated in another hospital; and (c) patients who died after trauma because, according to the current Italian Law, legal autopsy findings cannot be disclosed to the physicians in charge.

All patients were intubated and mechanically ventilated throughout their ICU admission; sepsis and sepsis-related conditions, including severe sepsis and septic shock, were treated according to the current guidelines [13]. All patients with cardiac arrest were admitted directly from the ER.

The university hospital in which our ICU is situated has an autopsy rate of $48 \%$, which remained stable over the past two decades. The autopsies were performed by a single experienced pathologist with a peculiar expertise in critically ill patients (RB).

All the autoptical records were screened and when a solid or hematologic tumor was found, the relative discharge diagnosis was cross-checked; when the neoplasm was not mentioned, the corresponding medical record was retrieved and a number of data were collected, including (a) all the relevant personal and clinical informations including age, gender, history, cause of admission, length of stay in ICU (LOS ICU), SOFA score the day of admission and the radiologic investigations performed; and (b) the type and location of the tumor discovered at the autopsy.

Each positive case was discussed by all the authors and the MD were classified according the Goldman's criteria in [14]: major MD with or without effects on the management and the outcome are included in Class 1 and 2, respectively, whereas Class 3 and 4 are minor MD (Table 1).

\begin{tabular}{|c|c|c|}
\hline Category & Class & Definitions \\
\hline \multirow[t]{2}{*}{$\begin{array}{l}\text { Major } \\
\text { Discrepancies }\end{array}$} & 1 & $\begin{array}{l}\text { A correct diagnosis and treatment could have } \\
\text { changed the outcome }\end{array}$ \\
\hline & 2 & $\begin{array}{l}\text { A correct diagnosis and treatment could NOT have } \\
\text { changed the outcome }\end{array}$ \\
\hline \multirow[t]{2}{*}{$\begin{array}{l}\text { Minor } \\
\text { Discrepancy }\end{array}$} & 3 & $\begin{array}{l}\text { Missed terminal disease unrelated with the cause of } \\
\text { death }\end{array}$ \\
\hline & 4 & Other missed diagnosis unrelated to death \\
\hline $\begin{array}{l}\text { No } \\
\text { discrepancies }\end{array}$ & 5 & No missed diagnosis \\
\hline $\begin{array}{l}\text { Not } \\
\text { classifiable }\end{array}$ & 6 & $\begin{array}{l}\text { Patients dead immediately after the admission, } \\
\text { diagnostic workup incomplete or absent, autopsy } \\
\text { inconclusive }\end{array}$ \\
\hline
\end{tabular}

Table 1: Classification of diagnostic discrepancies according to their effect on the outcome.

We used the free software R for statistical analysis (R Development Core Team, R Foundation for Statistical computing, Vienna, Austria 2008). The statistical analysis was performed with the Fisher's exact $t$ test; a $\mathrm{p}<0.05$ was considered statistically significant.

\section{Results}

In the considered period, 1045 autopsies were performed on patients died in our ICU (Figure 1).

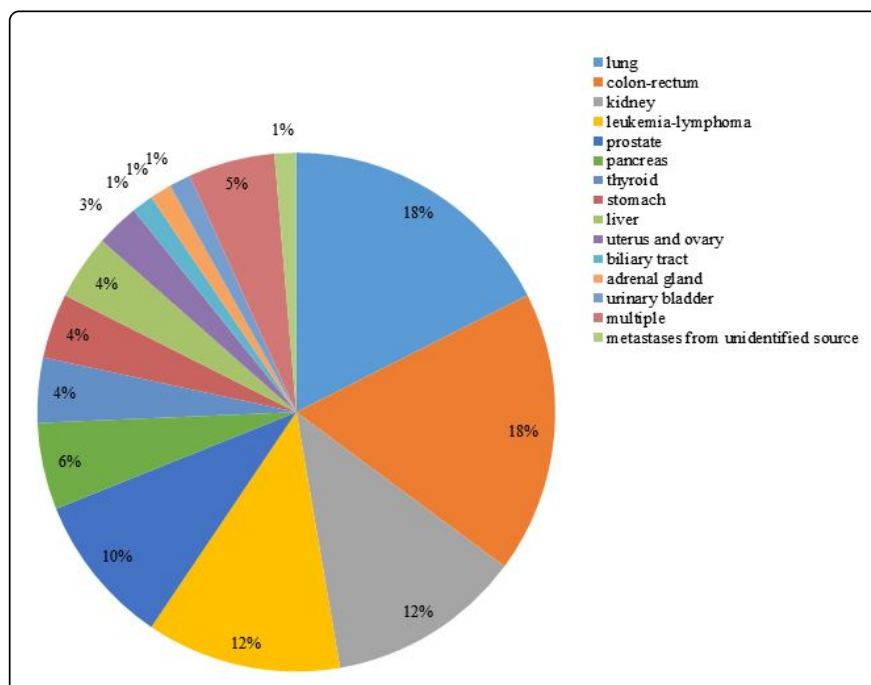

Figure 1: Distribution of tumors.

Overall, a solid or hematologic cancer was discovered in 74 patients (7.0\%, $50 \mathrm{M}, 24 \mathrm{~F}$, age 75.5, IQR 29-90 years). In no case a suspected diagnosis of tumor was reported on the medical records of the wards where patients were initially admitted. Albeit virtually every organ and system was involved, the missed solid tumors were located prevalently in the lung, digestive tract, prostate and kidney. During autopsy, in the $29.7 \%$ of patients with solid tumor were found a regional lymph nodes involvement and distant metastasis; regarding the hematologic cancers, in the $63.6 \%$ of cases were found an infiltration and invasion of the bone marrow, spleen, liver and lymph nodes. Patients with MD were subdivided into seven categories according to the causes of ICU admission. Overall, the rate of major MD was $58 \%$ for patients admitted due to respiratory failure, $83 \%$ for severe sepsis/septic shock, $38 \%$ for postoperative complications, $45 \%$ for haemorrhagic/ cardiogenic shock, $71 \%$ for cardiac arrest and none for intra-cerebral hemorrhage (Figure 2).

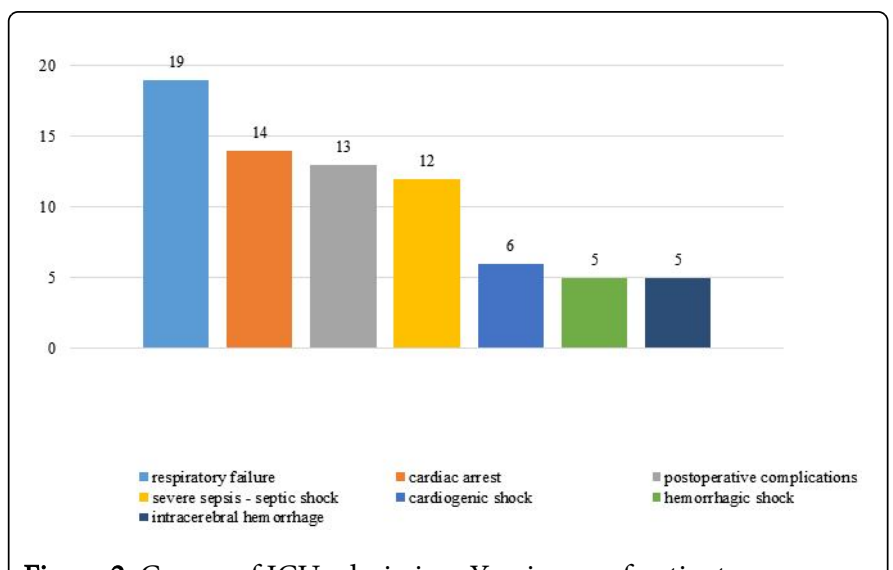

Figure 2: Causes of ICU admission. Y-axis: no. of patients. 
Page 3 of 8

The autoptical results, class of MD, radiological investigations and findings and $\mathrm{LOS}_{\mathrm{ICU}}$ are reported separately for each category apart cerebral hemorrhage for which no major MD were found (Table 2).

\begin{tabular}{|c|c|c|c|c|c|}
\hline $\begin{array}{l}\text { Goldman's } \\
\text { class }\end{array}$ & Category & $\begin{array}{l}\text { Total } \\
\text { no. }\end{array}$ & $\begin{array}{l}\text { Solid } \\
\text { tumors }\end{array}$ & $\begin{array}{l}\text { Hematological } \\
\text { tumors }\end{array}$ & $\begin{array}{l}\text { Multiple } \\
\text { tumors }\end{array}$ \\
\hline 1 & \multirow[t]{2}{*}{ Major MD } & 1 & 1 & 0 & 0 \\
\hline 2 & & 41 & 30 & 9 & 2 \\
\hline 3 & \multirow[t]{2}{*}{ Minor MD } & 32 & 30 & 0 & 2 \\
\hline 4 & & 0 & 0 & 0 & 0 \\
\hline
\end{tabular}

Forty-five patients $(61 \%)$ had a $\operatorname{LOS}_{\mathrm{ICU}}<24$ hours; their distribution is uneven, ranging from $37 \%$ of those admitted for respiratory failure to $100 \%$ of those admitted for haemorrhagic or cardiogenic shock. Two patients (10\%) admitted for respiratory failure, other two (17\%) of those admitted for severe sepsis or septic shock and one admitted for intra-cerebral hemorrhage had a $\operatorname{LOS}_{\mathrm{ICU}}>14$ days.

We identified a Class $1 \mathrm{MD}$ in one case (2.4\%). In the other cases the severity of the conditions determining the ICU admission and/or the short LOS ICU justified both the poor outcome and the lack of a more in-depth diagnostic workup; other MD had no relationship with the clinical course or constituted only incidental findings (Tables 3 and 4).

Table 2: Impact of MD (missed diagnoses) of tumor on the outcome.

\begin{tabular}{|c|c|c|c|c|c|c|c|}
\hline No. & Cancer & Histological type & $\begin{array}{l}\text { Radiologic } \\
\text { investigations }\end{array}$ & Radiologic findings & $\begin{array}{l}\text { Goldman's } \\
\text { class }\end{array}$ & $\operatorname{LOS}_{I C U}$ & $\begin{array}{l}\text { SOFA score } \\
\left(1^{\text {st }} \text { day }\right)\end{array}$ \\
\hline 1 & Lung & Adenocarcinoma & CRX & Negative & 2 & 5 days & 11 \\
\hline 2 & Bladder & Urothelial carcinoma & CT abdomen & Negative & 3 & 12 days & 10 \\
\hline 3 & Thyroid & Papillary carcinoma & Head and Neck CT & $\begin{array}{l}\text { Enlarged laterocervical } \\
\text { nodes }\end{array}$ & 3 & 8 days & 8 \\
\hline 4 & Lung & Adenocarcinoma & CRX & ARDS & 2 & 11 days & 5 \\
\hline 5 & Lymphoma & T-cell lymphoma & $\begin{array}{l}\text { CRX, } \\
\text { abdominal US }\end{array}$ & Negative & 2 & $<24$ hours & 10 \\
\hline 6 & Colon & Adenocarcinoma & CT abdomen & Negative & 3 & $<24$ hours & 16 \\
\hline 7 & Lymphoma & B-cell non Hodgkin lymphoma & CRX & Negative & 2 & 5 days & 5 \\
\hline 8 & Lung & Adenocarcinoma & CRX & Single pulmonary opacity & 2 & 11 days & 4 \\
\hline 9 & Stomach & Adenocarcinoma & CRX & Negative & 2 & 1 day & 9 \\
\hline 10 & Colon-prostate & Both adenocarcinoma & CRX & Negative & 3 & $<24$ hours & 9 \\
\hline 11 & Lung & Adenocarcinoma & CRX & Mediastinal widening & 2 & 1 day & 12 \\
\hline 12 & Colon & Adenocarcinoma & Abdominal US & Negative & 3 & $<24$ hours & 8 \\
\hline 13 & Lung & Adenocarcinoma & $\mathrm{CRX}$ & Single pulmonary opacity & 1 & 53 days & 5 \\
\hline 14 & Lung & Adenocarcinoma & CRX & Pleural effusion & 2 & $<24$ hours & 9 \\
\hline 15 & Lung & Adenocarcinoma & None & N.A. & 2 & $<24$ hours & 5 \\
\hline 16 & Kidney & Renal cell carcinoma & Abdominal US & Negative & 3 & 5 days & 3 \\
\hline 17 & Pancreas & Adenocarcinoma & CRX & Right lung opacity/ARDS & 2 & $<24$ hours & 11 \\
\hline 18 & Kidney & Renal cell carcinoma & CRX & ARDS & 3 & 10 days & 10 \\
\hline 19 & Thyroid & Papillary carcinoma & CRX & Multiple lung opacities & 3 & 30 days & 9 \\
\hline
\end{tabular}

Table 3: Radiologic investigations, $\mathrm{LOS}_{\mathrm{ICU}}$, and postmortem findings in patients admitted due to respiratory failure. Legend: CRX: plain chest Xray; US: ultrasonography; ARDS: acute respiratory distress syndrome; N.A.: not applicable.

\begin{tabular}{|l|l|l|l|l|l|l|l|}
\hline No. & Cancer & Histological type & $\begin{array}{l}\text { Radiologic } \\
\text { investigations }\end{array}$ & $\begin{array}{l}\text { Radiologic } \\
\text { findings }\end{array}$ & $\begin{array}{l}\text { Goldman's } \\
\text { class }\end{array}$ & LOS ICU $_{\text {ICU }}$ & $\begin{array}{l}\text { SOFA score } \\
\left(1^{\text {st }} \text { day }\right)\end{array}$ \\
\hline 1 & Leukemia & AML & CRX & Negative & 2 & $<24$ hours & 12 \\
\hline
\end{tabular}




\begin{tabular}{|c|c|c|c|c|c|c|c|}
\hline 2 & Lung & Adenocarcinoma & Lung CT & $\begin{array}{l}\text { Massive pulmonary } \\
\text { opacity }\end{array}$ & 2 & $<24$ hours & 5 \\
\hline 3 & Thyroid & Papillary carcinoma & CRX, abdominal CT & Negative & 3 & 22 days & 9 \\
\hline 4 & Pancreas & Adenocarcinoma & Abdominal US & Negative & 2 & $<24$ hours & 12 \\
\hline 5 & $\begin{array}{l}\text { Stomach and } \\
\text { pancreas }\end{array}$ & Mucinous adenocarcinoma & $\begin{array}{l}\mathrm{CRX}, \quad \text { abdominal } \\
\text { and lung } \mathrm{CT}\end{array}$ & Negative & 2 & 5 days & 10 \\
\hline 6 & Leukemia & AML & $\begin{array}{l}\text { Abdominal and lung } \\
\text { CT }\end{array}$ & Negative & 2 & $<24$ hours & 10 \\
\hline 7 & Leukemia & AML & $\mathrm{RX}$, abdominal CT & Negative & 2 & $<24$ hours & 15 \\
\hline 8 & Biliary tract & Cholangiocarcinoma & $\begin{array}{l}\text { Percutaneous } \\
\text { colangiography }\end{array}$ & Negative & 2 & 20 days & 6 \\
\hline 9 & $\begin{array}{l}\text { Colon and } \\
\text { rectum }\end{array}$ & Adenocarcinoma & CRX & Negative & 3 & 6 days & 3 \\
\hline 10 & Leukemia & AML & None & N.A. & 2 & $<24$ hours & 9 \\
\hline 11 & Leukemia & ALL & CRX & Negative & 2 & $<24$ hours & 15 \\
\hline 12 & Liver & Hepatocellular carcinoma & Abdominal CT & Liver infarction & 2 & $<24$ hours & 13 \\
\hline
\end{tabular}

Table 4: Radiologic investigations and findings, $\operatorname{LOS}_{\mathrm{ICU}}$, and postmortem findings in patients admitted due to severe sepsis and septic shock. Legend: CRX: plain chest X-ray; US: ultrasonography; N.A. not applicable.

\section{Discussion}

There is an on-going debate between supporters of autopsy and others who consider the post mortem investigation somehow outdated. The former advocate its use mainly to verify the overall diagnostic and therapeutic appropriateness and thus to reduce avoidable deaths by identifying MD which could have influence negatively the outcome both in patients died in the regular wards and in the ICU [14-16,9], whereas the latter claim that its value is reduced, but not totally abolished, in the era of unrelenting advances of the imaging techniques $[17,18]$. Besides these, in the past years other factors contributed to determine a worldwide decrease in the rate of autopsies in patients died in the hospital, including poor training of pathologists in its execution, costs and the fear of litigation (Table 5-7) $[19,20]$.

\begin{tabular}{|c|c|c|c|c|c|c|c|}
\hline No. & Cancer & Histological type & $\begin{array}{l}\text { Radiologic } \\
\text { investigations }\end{array}$ & $\begin{array}{l}\text { Radiologic } \\
\text { findings }\end{array}$ & $\begin{array}{l}\text { Goldman's } \\
\text { class }\end{array}$ & $\operatorname{LOS}_{I C U}$ & $\begin{array}{l}\text { SOFA score } \\
\left(1^{\text {st }} \text { day }\right)\end{array}$ \\
\hline 1 & Kidney & Renal cell carcinoma & Abdominal CT & Negative & 3 & $<24$ hours & 10 \\
\hline 2 & Kidney & Renal cell carcinoma & Abdominal CT & Benign renal cyst & 3 & 5 days & 10 \\
\hline 3 & Pancreas & Mucinous adenocarcinoma & Abdominal CT & $\begin{array}{l}\text { Pancreatic pseudo cyst/ } \\
\text { abscess }\end{array}$ & 2 & $<24$ hours & 6 \\
\hline 4 & Kidney & Renal cell carcinoma & Head CT & Negative & 3 & 5 days & 7 \\
\hline 5 & Stomach & Mucinous adenocarcinoma & CRX & Negative & 2 & $<24$ hours & 10 \\
\hline 6 & Colon rectum & Adenocarcinoma & Abdominal $\mathrm{CT}$ & Negative & 3 & 4 days & 15 \\
\hline 7 & Colon rectum & Adenocarcinoma & CRX & Negative & 2 & 3 days & 9 \\
\hline 8 & Colon rectum & Adenocarcinoma & None & N.A. & 3 & $<24$ hours & 4 \\
\hline 9 & Kidney & Renal cell carcinoma & Abdominal CT & Benign renal cyst & 3 & 12 days & 9 \\
\hline 10 & Uterus ovary & Adenocarcinoma & CRX & Negative & 3 & $<24$ hours & 4 \\
\hline 11 & Colon rectum & Adenocarcinoma & Abdominal CT & Negative & 2 & $<24$ hours & 7 \\
\hline 12 & Lung & Biphasic blastoma & CRX & Negative & 3 & $<24$ hours & 16 \\
\hline
\end{tabular}


Citation: Berlot G, Calderan C, Moro V, Bussani R, Zandonà L (2016) Missed Diagnosis of Cancer in Critically III Patients: A Single-Center

Page 5 of 8

\begin{tabular}{|l|l|l|l|l|l|l|l|}
\hline 13 & Lung & Squamous cell carcinoma & CRX & Negative & 2 & $<24$ hours & 4 \\
\hline
\end{tabular}

Table 5: Radiologic investigations and findings, $\mathrm{LOS}_{\mathrm{ICU}}$, and autopsy results in patients admitted for postoperative complications. Legend: CRX: plain chest X-ray; N.A. not applicable.

\begin{tabular}{|c|c|c|c|c|c|c|c|c|}
\hline \multirow[t]{6}{*}{ Hemorrhagic shock } & No. & Cancer & $\begin{array}{l}\text { Histological } \\
\text { type }\end{array}$ & $\begin{array}{l}\text { Radiologic } \\
\text { investigations }\end{array}$ & $\begin{array}{l}\text { Radiologic } \\
\text { findings }\end{array}$ & $\begin{array}{l}\text { Goldman's } \\
\text { class }\end{array}$ & $\operatorname{LOS}_{I C U}$ & $\begin{array}{l}\text { SOFA score } \\
\left(1^{\text {st }} \text { day }\right)\end{array}$ \\
\hline & 1 & Kidney & $\begin{array}{l}\text { Renal cell } \\
\text { carcinoma }\end{array}$ & None & N.A. & 3 & $<24$ hours & 5 \\
\hline & 2 & Leukemia, lung & $\begin{array}{l}\text { AML, Squamous } \\
\text { cell carcinoma }\end{array}$ & None & N.A. & 2 & $<24$ hours & 5 \\
\hline & 3 & Leukemia & AML & None & N.A. & 2 & $<24$ hours & 14 \\
\hline & 4 & Prostate & Adenocarcinoma & None & N.A. & 2 & $<24$ hours & 15 \\
\hline & 5 & Liver & $\begin{array}{l}\text { Hepatocellular } \\
\text { carcinoma }\end{array}$ & CRX & Negative & 2 & $<24$ hours & 7 \\
\hline \multirow[t]{6}{*}{ Cardiogenic shock } & 6 & Adrenal gland & Adenocarcinoma & None & N.A. & 3 & $<24$ hours & 5 \\
\hline & 7 & Prostate & Adenocarcinoma & None & N.A. & 3 & $<24$ hours & 12 \\
\hline & 8 & Stomach & Adenocarcinoma & EGDS & Negative & 3 & $<24$ hours & 7 \\
\hline & 9 & Uterus, ovary & Adenocarcinoma & None & N.A. & 3 & $<24$ hours & 6 \\
\hline & 10 & Colon, rectum & Adenocarcinoma & None & N.A. & 3 & $<24$ hours & 6 \\
\hline & 11 & Liver & $\begin{array}{l}\text { Hepatocellular } \\
\text { carcinoma }\end{array}$ & EGDS & Negative & 2 & $<24$ hours & 7 \\
\hline
\end{tabular}

Table 6: Radiologic investigations, LOSICU, and postmortem findings in patients admitted due to hemorrhagic and cardiogenic shock. Legend: CRX: chest X-ray; EGDS. Esophagogastroduodenalscopy, N.A. not applicable.

\begin{tabular}{|c|c|c|c|c|c|c|c|}
\hline No. & Cancer & Histological type & $\begin{array}{l}\text { Radiologic } \\
\text { investigations }\end{array}$ & $\begin{array}{l}\text { Radiologic } \\
\text { findings }\end{array}$ & $\begin{array}{l}\text { Goldman's } \\
\text { class }\end{array}$ & $\operatorname{LOS}_{\mathrm{ICU}}$ & $\begin{array}{l}\text { SOFA score } \\
\left(1^{\text {st }} \text { day }\right)\end{array}$ \\
\hline 1 & Colon rectum & Adenocarcinoma & None & N.A. & 2 & $<24$ hours & 6 \\
\hline 2 & Lung. Myeloma & $\begin{array}{l}\text { Neuroendocrine cell carcinoma, } \\
\text { myeloma }\end{array}$ & CRX & $\begin{array}{l}\text { Pulmonary opacity } \\
\text { (pneumonia?) }\end{array}$ & 3 & 5 days & 7 \\
\hline 3 & Colon rectum & Adenocarcinoma & None & N.A. & 2 & $<24$ hours & 9 \\
\hline 4 & Lung & Adenocarcinoma & Lung CT & Pulmonary abscess & 2 & 2 days & 14 \\
\hline 5 & Leukemia & AML & CRX, lung $\mathrm{CT}$ & Negative & 2 & 7 days & 4 \\
\hline 6 & Kidney & Renal cell carcinoma & None & N.A. & 3 & $<24$ hours & 10 \\
\hline 7 & Lung & Adenocarcinoma & CRX & $\begin{array}{l}\text { Pulmonary opacity } \\
\text { (pneumonia) }\end{array}$ & 2 & $<24$ hours & 7 \\
\hline 8 & $\begin{array}{l}\text { Liver, colon } \\
\text { rectum }\end{array}$ & $\begin{array}{l}\text { Hepatocellular } \\
\text { adenocarcinoma }\end{array}$ & CRX & Negative & 2 & $<24$ hours & 7 \\
\hline 9 & Colon rectum & Adenocarcinoma & CRX, abdominal CT & Negative & 2 & 11 days & 5 \\
\hline 10 & Pancreas & Adenocarcinoma & None & N.A. & 2 & $<24$ hours & 3 \\
\hline 11 & Colon & Adenocarcinoma & None & N.A. & 2 & $<24$ hours & 7 \\
\hline 12 & Prostate & Adenocarcinoma & CRX & Negative & 3 & 3 days & 10 \\
\hline
\end{tabular}




\begin{tabular}{|l|l|l|l|l|l|l|l|}
\hline 13 & Prostate & Adenocarcinoma & CRX & Negative & 3 & $<24$ hours & 3 \\
\hline 14 & Prostate & Adenocarcinoma & Abdominal RX & Negative & 2 & $<24$ hours & 2 \\
\hline
\end{tabular}

Table 7: Radiologic investigations, $\mathrm{LOS}_{\mathrm{ICU}}$, and postmortem findings in patients admitted due to cardiac arrest. Legend: CRX: chest X-ray; N.A. not applicable.

Actually, even if some investigators demonstrated that in patients admitted to regular wards the occurrence of major MD decreased along two or three decades [21,22], other studies showed that in patients died in the ICU the rate of potentially treatable conditions escaping to the clinical and radiologic investigations remains relatively high primarily because of the elevated lack of specificity of the symptoms prompting the ICU admission and to the rapidly evolving clinical conditions $[1,9]$. Moreover, it is likely that the already compromised conditions of critically ill patients could amplify the effects of some MD making them more vulnerable [23]. Although several investigations have been dedicated to the MD in patients died with already diagnosed malignancies $[24,25]$ the issue of neoplastic diseases discovered only during the autopsy in ICU patients admitted for other reasons has not been specifically addressed. Yet we guess that this topic is relevant for a number of reasons, including the everadvancing age of critically ill patients with the subsequent risk of underlying tumors, their prolonged LOS $_{\text {ICU }}[26$ ] and the need for a correct triage aimed to restrict aggressive life-sustaining treatments to neoplastic patients who could realistically take advantage from them.

\section{Our findings deserve some remarks}

First, the overall rate of MD of tumors varies among different studies, ranging from $<4 \%$ to $50 \%$ of the autopsies performed in patients died either in regular wards and in ICU $[8,9,27]$; it is arguable that our relatively low rate of MD could be at least partly related to the above-enlisted exclusion criteria which impeded us to know the results of the autopsies performed in other categories of critically ill patients.

Second, the Goldman's classification is extremely useful but it does not take into consideration the length of stay, which is a rather important variable especially in patients with rapidly deteriorating conditions like many of those admitted in the ICU; as an example, by excluding patients with a $\mathrm{LOS}_{\mathrm{ICU}} \leq 24$ hours from our study, the rate of MD of tumors would be almost halved (4\%): actually, it is likely that in these cases the extremely brief $\operatorname{LOS}_{\text {ICU }}$ limited the diagnostic workup to those life-threatening conditions responsible of the admission. On the other hand, a prolonged LOS did not guarantee against the presence of major $\mathrm{MD}$, as they were encountered also in chronic critically ill patients whose $\operatorname{LOS}_{\mathrm{ICU}}$ exceeded two weeks.

Third, as far as the site of tumor is concerned, our results partly differ from that those reported by Grinberg et al. [28] who observed a similar rate of lung cancers but higher ones of pancreatic and liver cancers; however, dissimilarly from the overall distribution of tumors which approaches that recorded in Italy with an elevated incidence of lung, colon and prostate tumors [29], no case of breast cancer was observed in female patients; we hypothesize that this finding could be primarily attributable to the widespread campaigns of screening initiated many years ago and are actively on-going.

Fourth, the MD of lung cancer occurred notwithstanding virtually every patient with a $\operatorname{LOS}_{\text {ICU }}>24$ hours and many of those with a LOS $_{\text {ICU }}$ below this threshold underwent one or more chest radiograph
(CRX) or chest CT scan due to the cause of ICU admission or to conditions occurred thereafter. Actually, despite the advances of the techniques, all radiological investigations have some inherent limitations: as far as the sensitivity of CRX outside the ICU is concerned, some investigators demonstrated that as many as $19 \%$ of early lung cancer are missed with the chest radiograph [30,31]; also the chest CT-scan is not flawless: Wichmann et al. [32] compared conventional vs. CT autopsies and demonstrated that, albeit medical autopsies are less sensitive to detect traumatic injuries, the opposite occurs for cancer. Other circumstances can further complicate the diagnosis in critically ill mechanically ventilated patients: actually, despite its widespread use, in ICU patients the CRX appears particularly at risk of misinterpretation since it is usually obtained with mobile radiographic devices in the frontal view, whereas the lateral view can enlighten abnormalities unrecognizable when only the anteroposterior film is achieved [30]. Moreover, with both the CRX and the CT scan the lung cancers can be misdiagnosed with different radiologic abnormalities more commonly encountered in mechanically ventilated critically ill patients, including pneumonia, ARDS and pleural effusions which can cover or mask the underlying neoplasm $[33,34]$.

Fifth, we did not measure the blood concentration of specific tumor markers, including the $\alpha$-fetoprotein, the carcino-embrional antigen etc. because their blood value by itself is not a specific or sensible indicator of tumor; moreover, in critically ill patients their elevation can be ascribed to factors other than neoplasms such as the systemic inflammatory response syndrome or sepsis and sepsis-derived conditions which affected most if not all the ICU patients [35]; the same consideration applies for the measurement of the mediators of inflammation, including the C-reactive protein and procalcitonin, although their elevation has been advocated as an early marker of still asymptomatic neoplasms [36]; actually, they were repeatedly measured during the $\operatorname{LOS}_{\mathrm{ICU}}$, and resulted constantly altered most likely due to the presence of infections and other conditions associate with the release of pro-inflammatory substances [37,38].

Sixth, in one case only the MD of lung tumor was considered a Class 1 error as it occurred in a patients with a prolonged LOS $_{\text {ICU }}$ which should have prompted more in-depth clinical investigations; the other major discrepancies observed have been considered belonging to the Class 2 as they occurred in patients whose coexistent conditions leading to the ICU admission were so critical that a correct diagnosis and treatment of tumor could not have changed the outcome and/or the LOS $_{\text {ICU }}$ has been extremely brief ; in the other cases the MD was considered unrelated to the cause of death and thus categorized as Class 3 and 4 errors. We are aware that this finding is in contrast with the rate of $8 \%$ of Class 1 errors reported by a recent meta-analysis but these major MD consists primarily in acute cardiac and respiratory conditions and not by tumors such as in the current study [39].

It is arguable that if some patients with Class 2 errors would have been discharged alive from the ICU further investigations performed in the admitting ward would have been able to identify the tumor. 
Finally, independently from the continuous advances in the clinical and radiological investigations, MD still represents an entity hard to eliminate especially in patients, such as those admitted to the ICU, whose symptoms can be interpreted in many ways, ascribed to a number of different conditions and/or are rapidly evolving. In these circumstances, in our as well as in other's experience, autopsy remain an essential tool either to verify the appropriateness of the procedures and to recognize the limitations of other diagnostic tools.

\section{Conclusions}

In patients died in our ICU for reasons other than a neoplastic disease, a solid or hematologic cancer was found in $7 \%$ of cases; $57 \%$ of these MD were classified as a major discrepancy. Although $61 \%$ of

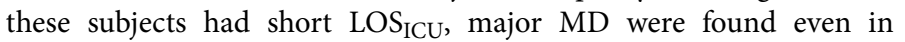
patients with chronic critical diseases.

\section{References}

1. Maris C, Martin B, Creteur J, Remmelink M, Piagnerelli M, et al. (2007) Comparison of clinical and post-mortem findings in intensive care unit patients. Virchows Arch 450: 329-333.

2. Burton JL, Underwood J (2007) Clinical, educational, and epidemiological value of autopsy. Lancet 369: 1471-1480.

3. van den Tweel JG, Wittekind C (2016) The medical autopsy as quality assurance tool in clinical medicine: dreams and realities. Virchows Arch 468: 75-81.

4. Tejerina E, Esteban A, Fernández-Segoviano P, Frutos-Vivar F, Aramburu J, et al. (2010) Accuracy of clinical definitions of ventilator-associated pneumonia: comparison with autopsy findings. J Crit Care 25: 62-68.

5. Berlot G, Vergolini A, Calderan C, Bussani R, Torelli L, et al. (2010) Acute myocardial infarction in non-cardiac critically ill patients: a clinicalpathological study. Monaldi Arch Chest Dis 74:164-71.

6. Berlot G, Calderan C, Vergolini A, Bianchi M, Vivianiet M, et al. (2011) Pulmonary embolism in critically ill patients receiving antithrombotic prophylaxis: a clinical-pathologic study. J Crit Care 26: 28-33.

7. Kuijpers CC, Fronczek J, van de Goot FR, Niessen HW, van Diest PJ, et al. (2014) The value of autopsies in the era of high-tech medicine: discrepant findings persist. J Clin Pathol 67: 512-519.

8. Tejerina E, Esteban A, Fernández-Segoviano P, María Rodríguez-Barbero J, Gordo F, et al. (2012) Clinical diagnoses and autopsy findings: discrepancies in critically ill patients. Crit Care Med 40: 842-846.

9. Perkins GD, McAuley DF, Davies S, Gao F (2003) Discrepancies between clinical and postmortem diagnoses in critically ill patients: an observational study. Critical Care 7: R129-R132.

10. Podbregar M, Voga G, Krivec B, Skale R, Pareznik R, et al. (2001) Should we confirm our clinical diagnostic certainty by autopsies? Intensive Care Med 27: 1750-1755.

11. Neal RD, Tharmanathan P, France B, Din NU, Cotton S, et al. (2015) Is increased time to diagnosis and treatment in symptomatic cancer associated with poorer outcomes? Systematic review. Br J Cancer 112: S92-S107.

12. Taccone FS, Artigas AA, Sprung CL, Moreno R, Sakr Y, et al. (2009) Characteristics and outcomes of cancer patients in European ICUs. Crit Care 13: R15.

13. Dellinger RP, Mitchell ML, Rhodes A, Annane D, Gerlach H, et al. (2013) Surviving Sepsis Campaign: International Guidelines for Management of Severe Sepsis and Septic Shock, 2012. Intensive Care Med 39:165-228.

14. Goldman L, Sayson R, Robbins S, Cohn LH, Bettmann M, et al. (1983) The value of the autopsy in three medical eras. N Engl J Med 308: 1000-1005.

15. De Vlieger GY, Mahieu EM, Meersseman W (2010) Clinical review: What is the role for autopsy in the ICU? Crit Care 14: 221.
16. Combes A, Mokhtari M, Couvelard A, Trouillet JL, Baudot J, et al. (2004) Clinical and autopsy diagnoses in the intensive care unit: a prospective study. Arch Intern Med 164: 389-392.

17. Roberts IS, Benamore RE, Benbow EW, Lee SH, Harris JN, et al. (2012) Post-mortem imaging as an alternative to autopsy in the diagnosis of adult deaths: a validation study. Lancet 379: 136-142.

18. Fröhlich S, Ryan O, Murphy N, McCauley N, Crotty T, et al. (2014) Are autopsy findings still relevant to the management of critically ill patients in the modern era? Crit Care Med 42: 336-343.

19. Lemaire F (2003) Should the autopsy be resuscitated? Intensive Care Med 29: 518-521.

20. Esteban A, Fernández-Segoviano P (1999) The autopsy as a tool to monitor diagnostic error. Intensive Care Med 25: 343-344.

21. Sonderegger-Iseli K, Burger S, Muntwyler J, Salomon F (2000) Diagnostic errors in three medical eras: a necropsy study. Lancet 355: 2027-2031.

22. Shojania KG, Burton EC, McDonald KM, Golman L (2003) Changes in rates of autopsy-detected diagnostic errors over time. A systematic review. JAMA 289: 2849-2856.

23. Garrouste-Orgeas M, Timsit JF, Vesin A (2010) Selected Medical Errors in the Intensive Care Unit. Results of the IATROREF Study: Parts I and II. Am J Respir Crit Care Med 181: 134-142.

24. Xavier AC, Siqueira SA, Costa LJ, Mauad T, Nascimento Saldiva PH (2005) Missed diagnosis in hematological patients-an autopsy study. Virchows Arch 446: 225-231.

25. Pastores SM, Dulu A, Voigt L, Raoof N, Alicea M, et al. (2007) Premortem clinical diagnoses and postmortem autopsy findings: discrepancies in critically ill cancer patients. Crit Care 11: R48.

26. Moitra VK, Guerra C, Linde-Zwirble WT, Wunsch H (2016) Relationship Between ICU Length of Stay and Long-Term Mortality for Elderly ICU Survivors. Crit Care Med 44: 655-662.

27. Thurnheer R, Hoess C, Doenecke C, Moll C, Muntwyler J, et al. (2009) Diagnostic performance in a primary referral hospital assessed by autopsy: evolution over a ten-year period. Eur J Intern Med 20: 784-787.

28. Grinberg LT, Ferraz da Silva LF, Galtarossa Xavier AC, Nascimento Saldiva PH, Mauad T (2008) Clinico-pathological discrepancies in the diagnoses of solid malignancies. Pathol Res Pract 204: 867-873.

29. Ferlay J, Steliarova-Foucher E, Lortet-Tieulent J, Rosso S, Coebergh JW, et al. (2013) Cancer incidence and mortality patterns in Europe: estimates for 40 countries in 2012. Eur J Cancer 49: 1374-1403.

30. Raoof S, Feigin D, Sung A, Raoof S, Irugulpati L, et al. (2012) Interpretation of plain chest roentgenogram. Chest 141: 545-558.

31. Quekel LG, Kessels AG, Goei R, van Engelshoven JM (1999) Miss rate of lung cancer on the chest radiograph in clinical practice. Chest 115: 720-724.

32. Wichmann D, Obbelode F, Vogel H, Hoepker WW, Nierhaus A, et al. (2012) Virtual autopsy as an alternative to traditional medical autopsy in the intensive care unit: a prospective cohort study. Ann Intern Med 156: 123-130.

33. Schwarz MI, Albert RK (2004) "Imitators" of the ARDS: implications for diagnosis and treatment. Chest 125: 1530-1535.

34. Gadkowski LB, Stout JE (2008) Cavitary pulmonary disease. Clin Microbiol Rev 21: 305-333.

35. Duffy MJ (2013) Tumor markers in clinical practice: a review focusing on common solid cancers. Med Princ Pract 22: 4-11.

36. Brenner DR, Scherer D, Muir K, Schildkraut J, Boffetta P, et al. (2014) A review of the application of inflammatory biomarkers in epidemiologic cancer research. Cancer Epidemiol Biomarkers Prev 23: 1729-1751.

37. Surbatovic M, Veljovic M, Jevdjic J, Popovic N, Djordjevic D, et al. (2013) Immunoinflammatory response in critically ill patients: severe sepsis and/or trauma. Mediators Inflamm 2013: 362793.

38. Markanday A (2015) Acute Phase Reactants in Infections: EvidenceBased Review and a Guide for Clinicians. Open Forum Infect Dis 2: ofv098. 
Citation: Berlot G, Calderan C, Moro V, Bussani R, Zandonà L (2016) Missed Diagnosis of Cancer in Critically III Patients: A Single-Center Experience. J Clin Exp Pathol 6: 299. doi:10.4172/2161-0681.1000299

Page 8 of 8

39. Winters B, Custer J, Galvagno SM Jr, Colantuoni E, Kapoor SG, et al. (2012) Diagnostic errors in the intensive care unit: a systematic review of autopsy studies. BMJ Qual Saf 21: 894-902. 